\title{
TOWARDS INVENTORY AND ASSESSMENT OF PLANT RESOURCES OF BANGLADESH: CHALLENGES AND PROSPECTS
}

\author{
Rahman, M. A. \\ Department of Botany, University of Chittagong, Chittagong 4331, Bangladesh
}

\begin{abstract}
This review is to appraise plant resources of Bangladesh. Contributions to the inventory, flora writing and establishment of National Herbarium in the country are discussed. The progress of Published Flora of Bangladesh since its independence with family name, number of genera and species including contributors' name is mentioned. Contributions of the botanists of the Dhaka University (DU), Chittagong University (CU), Jahangirnagar University (JU), Rajshahi University (RU), Bangladesh Forest Research Institute (BFRI), Bangladesh Council of Scientific and Industrial Research (BCSIR), Asiatic Society of Bangladesh and other institutions in botanical explorations and inventory of the flora are also mentioned. Assessment of threatened taxa, medicinal plant diversity, new discovery, new records, endemics, and production of Red Data Book are also considered as valuable entry in this study.
\end{abstract}

Key words: Plant resource; Inventory; Assessment; Progress; Bangladesh.

\section{INTRODUCTION}

Plant is one of the important environmental resources which indeed regulate the sustainability of environment. Each and every species of plant makes uncountable contribution to the environment for well-being of human through not only supplying food and basic needs, but by releasing oxygen and reducing carbon-dioxide in the nature which is universal truth. Sustainable utilization and conservation of plant resource of a country depend on its proper exploration, complete inventory and assessment which almost all developed countries have done like exploration of other environmental resources, e.g., coal, gas, oil and minerals. IUCN has developed guidelines for assessing, conserving, and sustainable using of biodiversity resources of every country following Convention on Biological Diversity (Articles 6-10). Flora is the result of inventory of plants of a country and Red Data Book (RDB) is the assessment result of its threatened plants. Hence production of Flora and RDB is urgently required for a country for determination, sustainable utilization, and conservation management of its biodiversity resources. Floristically, Bangladesh is one of the richest biodiversity areas in the Indian subcontinent estimating approximately c.5000 vascular angiosperms (Khan 1977, 1991) of which more than $80 \%$ species are Indian elements. The flora shows a considerable admixture of Cachar and Khasia elements. Floristically and geographically the region of Chittagong and the Hill Tracts is more related to Indo-China and Arakan than any other part of the Indian subcontinent. Plant scientists of Bangladesh, since its independence (1971), have started to contribute in conducting this inventory research, but the goal yet to be achieved. The present study is therefore envisaged to evaluate its progress made by Bangladeshi contributors since independence. The attempts are made to identify the actual problems on 'encountering' and 'priority to be given', and to trace out the possible prospects in achieving goals.

\section{THE TEXT}

Biodiversity loss is the process of losing species resulting from the continuous depletion of plants and animals population in a certain area of the biosphere. Unfortunately, quantifying the rates of species extinction, both at present and historically, is difficult, and predicting future rates with precision is impossible. Documenting definite species extinctions is only realistic under a relatively limited set of circumstances, where a described species is readily visible and has a well-defined range which can be 
surveyed repeatedly. Unsurprisingly, most documented extinctions are of species that are easy to record (e.g. land snails, birds) and inhabit sites which can be relatively easily inventoried (e.g. oceanic islands). Even then to face the species extinction and to realize the speciation, we shall have to go for proper assessment of the species richness and species evenness in an ecological area of our planet. It is equally important to make an inventory to exercise the procedural tools for species conservation and finally for the conservation of biodiversity. A little attempt is being initiated in the present article as a reviewexercise for the plant population of Bangladesh.

\section{Dhaka University and Bangladesh National Herbarium}

Professor M. Salar Khan of Dhaka University was one of the pioneer taxonomists of the Indian subcontinent. He was the 'Father of Plant Taxonomy' in Bangladesh. Professor Khan was an outstanding plant taxonomist. He had commendable contribution and dedication in the field of plant taxonomy and inventory of the flora. Prof. Khan initiated the floristic survey project for the first time based on the Herbarium of Botany Department of Dhaka University. He continued this by his own effort until May 1970 while the project was approved by the then Government as "Botanical Survey of East Pakistan" under the Agricultural Research Council of Pakistan. After independence, the project was sustained by the Government of Bangladesh until 1973 while it was taken up as a contract project under the Bangladesh Agricultural Research Council (BARC). Conducting botanical exploration and process of establishing a national herbarium began with renewed vigor in 1975 under a name of "Bangladesh National Herbarium" (Khan 1991a) and was set up in the BARC compound at Farmgate, Dhaka.

Prof. M.S. Khan along with his followers/ co-associates (AM Huq, MK Mia, Mahbuba Halim, and MM Rahman) and others of aforesaid Bangladesh National Herbarium project worked in inventorying the flora by exploring, collecting, determining and preserving the plant specimens. The workers made study throughout Bangladesh for about three decades. Lastly, by 1999 they achieved the goal in establishing a separate campus of Bangladesh National Herbarium with an independent building in Mirpur area of Dhaka city. The Herbarium is built just beside the National Botanical Garden under financial support of ODA (now DFID) of the UK. It is then housed with a preservation of about 100,000 specimens collected by Prof. Khan and others during three and half decades until 2005.

Professor Khan and his co-workers of the National Herbarium conducted floristic survey, family wise inventory and Flora writing, and he published the Flora of Bangladesh as the first volume (Fasc.1). This included five angiosperm families, viz. Caricaceae, Casuarinaceae, Hydrophyllaceae, Martyniaceae and Phytolaccaceae. The description of the families included with a single species in each case (Khan 1972). Since then, family wise taxonomic itemization and publication of the Flora of Bangladesh had been continued until 2002 (Khan 1972-1987, Khan and Rahman 1989-2002) edited by MS Khan and thereafter by others ( e.g. Rahman 2003, Rahman and Khanam 2003, Khanam and Ara 2004-2008, Ara and Khan 2009, 2014, 2015) from Bangladesh National Herbarium. To date only 75 families consisting of 629 species were completely inventoried so far and published in 63 fascicles of the Flora of Bangladesh during the last five decades since 1970 at a very slow progress. A list of Published Fascicles of the Flora with number of taxa is shown in Table 1. Nevertheless, it was made possible by the joint efforts of the taxonomists of National Herbarium, Dhaka University, Chittagong University and Bangladesh Forest Research Institute (BFRI). 
Table 1. Published Fascicles of the Flora of Bangladesh from National Herbarium with number of taxa and name of contributors.

\begin{tabular}{|c|c|c|c|c|}
\hline $\begin{array}{l}\text { Fasc. no./ Year } \\
\text { of publication }\end{array}$ & Family & No. of Genera & No. of Species & $\begin{array}{c}\text { Family wise contributors } \\
\text { (Family wise inventors) }\end{array}$ \\
\hline & Casuarinaceae & 1 & $\overline{1}$ & \\
\hline \multirow[t]{5}{*}{$1(1972)$} & Phytolaccaceae & 1 & 1 & M. S. Khan \& A. M. Huq \\
\hline & Hydrophyllaceae & 1 & 1 & \\
\hline & Martyniaceae & 1 & 1 & \\
\hline & Caricaceae & 1 & 1 & \\
\hline & Moringaceae & 1 & 1 & \\
\hline \multirow[t]{5}{*}{$2(1973)$} & Polemoriaceae & 1 & 1 & M. S. Khan \& A. M. Huq \\
\hline & Pedaliaceae & 1 & 1 & \\
\hline & Baselliaceae & 1 & 1 & \\
\hline & Butomaceae & 1 & 1 & \\
\hline & Ochnaceae & 1 & 1 & \\
\hline \multirow[t]{4}{*}{$3(1973)$} & Turneraceae & 1 & 1 & M. S. Khan \& A. M. Huq \\
\hline & Fumariaceae & 1 & 1 & \\
\hline & Tropaeolaceae & 1 & 1 & \\
\hline & Flagellariaceae & 1 & 1 & \\
\hline 4 (1977) & Commelinaceae & 13 & 27 & M. S. Khan \& M. K. Alam \\
\hline $5(1977)$ & Sphenocleaceae & 1 & 1 & M. S. Khan \& A. M. Huq \\
\hline $6(1977)$ & Onagraceae & 1 & 6 & M.S. Khan \&Shamshunnahar \\
\hline $7(1978)$ & Rhizophoraceae & 5 & 9 & M. S. Khan \\
\hline $8(1978)$ & Haloragaceae & 1 & 2 & M. S. Khan \& M. Halim \\
\hline $9(1979)$ & Nymphaceae & 5 & 8 & M. S. Khan \& M. Halim \\
\hline $10(1979)$ & Ceratophyllaceae & 1 & 2 & M. S. Khan \& M. Halim \\
\hline 11(1979) & Zannichelliaceae & 1 & 1 & M. S. Khan \& M. Halim \\
\hline $12(1980)$ & Sonneratiaceae & 2 & 5 & M. S. Khan \\
\hline $13(1980)$ & Buddeejaceae & 1 & 1 & M. S. Khan \& A. M. Huq \\
\hline $14(1980)$ & Cannabidaceae & 1 & 1 & M. S. Khan \& M. Halim \\
\hline $15(1981)$ & Oxalidaceae & 2 & 4 & M. S. Khan \& M. Begum \\
\hline $16(1981)$ & Zygophyllaceae & 1 & 1 & M. S. Khan \& A. M. Huq \\
\hline $17(1981)$ & Molluginaceae & 2 & 3 & M. S. Khan \& M. Halim \\
\hline $18(1982)$ & Averrhoaceae & 1 & 2 & M. S. Khan \&A. M. Huq \\
\hline $19(1982)$ & Ruppiaceae & 1 & 1 & M. S. Khan \& M. Halim \\
\hline $20(1982)$ & Salicaceae & 1 & 1 & A. M. Huq \\
\hline $21(1983$ & Orobanchachaceae & 2 & 4 & M. Begum \& A. M. Huq \\
\hline $22(1983)$ & Punicaceae & 1 & 1 & M. Halim \\
\hline $23(1983)$ & Dichapetalaceae & 1 & 1 & A. M. Huq \\
\hline $24(1984)$ & Pontederiaceae & 2 & 3 & M. M. Rahman \& M. Halim \\
\hline $25(1984)$ & Dipterocarpaceae & 5 & 8 & M. S. Khan \\
\hline $26(1984)$ & Linaceae & 2 & 2 & M. M. K. Mia \& A. M. Huq \\
\hline $27(1984)$ & Trapaceae & 1 & 2 & M. S. Khan \&M. Halim \\
\hline $28(1985)$ & Hydrocharitaceae & 6 & 9 & M. S. Khan \& M. Halim \\
\hline $29(1985)$ & Juncaceae & 1 & 1 & M. M. K. Mia \& A. M. Huq \\
\hline $30(1985)$ & Convolvulaceae & 15 & 59 & M. S. Khan \\
\hline $31(1986)$ & Aviceniaceae & 1 & 3 & M. K. Alam \& B. M. R. Khatun \\
\hline $32(1986)$ & Stylidiaceae & 1 & 2 & A. M. Huq \\
\hline $33(1986)$ & Loranthaceae & 7 & 15 & M. K. Alam \\
\hline 34 (1987) & Aizoaceae & 2 & 2 & M. S. Khan \& M. Halim \\
\hline $35(1987)$ & Bixaceae & 1 & 1 & M. S. Khan \& M. Halim \\
\hline $36(1987)$ & Burseraceae & 2 & 2 & A. M. Huq\& H. Hasan \\
\hline 37 (1988) & Peperomiaceae & 1 & 1 & B. Khan \\
\hline
\end{tabular}




\begin{tabular}{|c|c|c|c|c|}
\hline $38(1988)$ & Burmanniaceae & 1 & 1 & A. M. Huq \\
\hline 39 (1987) & Elatinaceae & 2 & 4 & S. Khan \& M. Halim \\
\hline 40 (1989) & Potamogetonaceae & 5 & 5 & S. Khan \& M. Halim \\
\hline $41(1989)$ & Stemonaceae & 1 & 1 & A. M. Huq\& M. M. Mirza \\
\hline $42(1989)$ & Plumbaginaceae & 2 & 4 & M. S. Khan \& B. Khan \\
\hline $43(1989)$ & Cassythaceae & 1 & 1 & M. S. Khan \& H. Ara \\
\hline $44(1990)$ & Hydrocotylaceae & 2 & 2 & A. M. Huq\& M. M. Rahman \\
\hline $45(1990)$ & Costaceae & 1 & 1 & M. M. K. Mia \&M.M. Rahman \\
\hline $46(1991)$ & Xyridaceae & 1 & 2 & M. S. Khan \& H. Ara \\
\hline $47(1991)$ & Periplocaceae & 6 & 7 & M. A. Rahman \& C. C. Wilcock \\
\hline $48(1995)$ & Asclepiadaceae & 26 & 56 & M. A. Rahman \& C. C. Wilcock \\
\hline 49 (1995) & Menyanthaceae & 1 & 4 & M. Khanam \\
\hline $50(1996)$ & Combretaceae & 6 & 20 & M. M. K. Mia \\
\hline $51(1996)$ & Menispermaceae & 14 & 16 & M. M. K. Mia \\
\hline $52(2002)$ & Annonaceae & 15 & 42 & M. Khanum\& M. M. Rahman \\
\hline $53(2002)$ & Solanaceae & 13 & 34 & M. S. Khan \& C. Mia \\
\hline $54(2003)$ & Malvaceae & 14 & 40 & M. S. Khan \& S. Hossain \\
\hline $55(2003)$ & Cuscutaceae & 1 & 6 & M. S. Khan \& M. Khanum \\
\hline $56(2007)$ & Dilleniaceae & 2 & 5 & S. N. Uddin \\
\hline 57 (2007) & Capparaceae & 4 & 13 & M.M.K. Mia, H. Ara \& B. Khan \\
\hline $58(2008)$ & Lamiaceae & 34 & 83 & M. Khanum\& M. A. Hassan \\
\hline $59(2009)$ & Sapindaceae & 12 & 21 & S. N. Uddin \\
\hline $60(2009)$ & Lecythidaceae & 3 & 6 & H. Ara \& M. A. Hassan \\
\hline $61(2014)$ & Rhamnaceae & 5 & 11 & H.Ara\& MA Hassan \\
\hline $62(2014)$ & Sabiaceae & 2 & 5 & S. N. Uddin \\
\hline $63(2015)$ & Vitaceae & 8 & 33 & M.E. Rashid \& M.A. Rahman \\
\hline $\begin{array}{l}\text { Fascicles: } 63 \\
\text { Duration: } 45 \text { yrs }\end{array}$ & Total families: 75 & $\begin{array}{l}\text { Total Genera: } \\
288\end{array}$ & $\begin{array}{l}\text { Total species: } \\
\quad 629\end{array}$ & No. of Contributors: 20 \\
\hline
\end{tabular}

\section{Contribution of other Institutions}

Since independence of Bangladesh, botanists of Dhaka University (DU), Chittagong University (CU), Jahangirnagar University (JU) and Rajshahi University (RU), Bangladesh Forest Research Institute (BFRI) and BCSIR (Bangladesh Council for Scientific and Industrial Research) Laboratories, Chittagong were involved in conducting botanical explorations throughout the flora independently as a part of their academic and research activities and post-graduate research projects which indeed parts of systematic survey towards the complete inventory of the flora. Under such research projects, a number of angiosperm families as well as a number of local floras were completely inventoried, checklists published and data with collections made available for Flora writing. This process of inventorying local floras through post graduate projects could enhance the progress of completing the whole flora. Based on this idea, MA Hassan and others of DU, ABM Enayet Hossain of JU, and MA Rahman and others of $\mathrm{CU}$, following MS Khan, were conducting inventories of local floras through postgraduate research projects. Some of the important local inventories made by different contributors are hereby mentioned below: Chittagong Hill Tracts (Khan and Banu1969, 1972); St. Martin's Island (Khan et al.1984); Moheskhali Island (Huq and Khan 1984); Hatia Island (Huq1988); Teknaf Game Reserve (Khan et al. 1994); Bhawal National Park (Rahman and Hassan 1995); Kutubdia (Huq1996); Sitakunda forest of Chittagong (Rahman and Uddin 1997); Chandra beel (Yusuf et al. 1997); Sitapahar at Kaptai (Uddin et al. 1998); Himchari National Park (Uddin and Rahman 1999); Chunati Wildlife Sanctuary (Khan and Huq 2001); Madhupur National Park (Rashid and Mia 2001); Rema-Kalenga Wildlife Sanctuary Monocot/Dicots (Uddin et al. 2002, 2003); Rema-Kalenga Wildlife Sanctuary (Uddin and Hassan 2004); Lalmai Hills (Hossain et al. 2005); Chittagong University Campus (Momen et al. 2006); 
Ramgarh upazila of Khagrachari (Islam et al. 2009); Runctia Sal Forest - Monocot/Dicots (Tutul et al. 2009, 2010); Ramgarh forest (Islam et al. 2009); Lawachara National Park (Uddin and Hassan 2010); Satchari National Park, Habiganj (Arefin et al. 2011); Rampahar reserve forest of Kaptai - Dicot (Rahman et al. 2012); Rampahar Reserve forest of Kaptai- Monocot (Uddin and Hassan 2012); Upper Rezu Reserve Forest (Uddin et al. 2013); Barayadhala NP (Rahman et al. 2015); Hakaluki Haor, ECA (Rahman et al. 2016) and Hazarikhil Wildlife Sanctuary (Rahman 2017). In the recent years, botany departments of different universities have produced a good number of quality taxonomists whom could not yet been engaged in the expected fields due to lack of government policy and initiation.

\section{University of Chittagong}

The floristic survey and collection of specimens towards the inventory of the south-east part of the Flora of Bangladesh has also been conducting under Aberdeen University (AU)-Chittagong University (CU) Biodiversity Link Project leaded by MA Rahman of CU and CC Wilcock of AU. The project was initially funded by DFID managed by the British Council of Dhaka for three years (1997-1999). Later the project was sustained through a small grant from Ministry of Agriculture through BARC and very recently by two other separate funds of the Ministry of Science \& Technology and the Ministry of Education. Professor Rahman and his co-workers explored more than $60 \%$ areas of the flora, collected, identified and preserved more than 10000 specimens at the Herbarium of Chittagong University (HCU). A number of Local floras and Family wise inventories were made, check lists published and data bank made available for Flora wring.

\section{Asiatic Society of Bangladesh}

In the recent years, the Asiatic Society of Bangladesh has published the Encyclopedia of Flora and Fauna of Bangladesh in 12 volumes, of which 7 volumes are with the compilation of angiosperms containing 3447 species in 199 families (Siddiqui 2007, Ahmed et al. 2008a, 2008b, 2008c, 2009a, 2009 b, 2009c). It was also made possible only due to the joint efforts of the taxonomists of Dhaka University, Chittagong University, Jahangirnagar University, Bangladesh National Herbarium (BNH), Bangladesh Forest Research Institute (BFRI) and Bangladesh Council for Scientific and Industrial Research (BCSIR) which was carried out under a 5-year project of the Asiatic Society of Bangladesh funded by the Ministry of Forest and Environment and the Ministry of Finance of the Government of Bangladesh. Among major contributors of the Encyclopedia of Flora and Fauna of Bangladesh, MA Hassan (Polygonaceae, Bignoniaceae, Bombacaceae), M Begum (Acanthaceae), MO Ullah (Cucurbitaceae, Euphorbiaceae) and A Ullah (Apiaceae) of Dhaka University; ABM Enayet Hossain (Asteraceae) of Jahangir Nagar University; MA Rahman (Asclepiadaceae, Apocynaceae, Periplocaceae, Rubiaceae, Vitaceae) and MK Huda (Ochidaceae) of Chittagong University; MK Alam (Commelinaceae, Fagaceae, Lorenthaceae) of BFRI; M Yusuf (Zingiberaceae) of BCSIR; M Khanam (Annonaceae, Lamiaceae), MM Rahman (Poaceae), MK Mia (Combretaceae, Menispermaceae), BM Rezia (Begoniaceae, Boraginaceae, Caesalpiniaceae), H Ara (Araceae, Rhamnaceae), B Khan (Convolvulaceae, Euphorbiaceae) and SN Uddin (Celastraceae) of National Herbarium, are noteworthy.

\section{Assessment/Inventory of threatened taxa and Production of Red Data Book}

Prof. M.S. Khan himself initiated the inventorying of threatened plants of the flora and produced first volume entitled, Red Data Book of Vascular Plants of Bangladesh (Khan et al. 2001) with 106 species from 46 families which covered only $2 \%$ of the estimated number of species (Rahman et al. 2010). The preparation of an additional list of threatened species with full details for the entry to the Red Data Book had also been conducted under Aberdeen University-Chittagong University (AU-CU) 
Biodiversity Link Project during 1997-2001, the first report was made by Rahman (2003) with 18 threatened species, and second report with 58 species (Rahman et al. 2010). The second volume of the Red Data Book of Vascular Plants of Bangladesh has also been produced by Ara et al. (2013) from National Herbarium with 120 threatened species under 58 families contributed by different authors. In these 2 volumes of RDB a total of 226 species, including 214 angiosperms and 4 gymnosperms and 8 pteridophytes, from different families were enumerated. This assessment of threatened taxa is not a family wise systematic inventory rather sporadic. However, family wise systematic inventory of threatened taxa has been initiated by MA Rahman of Chittagong University since 2010, and produced a Red Data Book of Flowering plants of Bangladesh (Rahman 2013) with the result of a complete inventory of 13 angiosperm families consisting of 235 taxa under different threatened categories including 69 species presumed to be extinct from the flora. Complete inventory result of these 13 families reveals that $41 \%$ species of Bangladesh are environmentally threatened and $11.5 \%$ are possibly lost from the flora which is an alarming to the sustainability of the environment.

\section{New discovery, new record and Endemics}

Since independence of Bangladesh, 12 new species and 2 new varieties were discovered from the flora of Bangladesh, these are, Ampelygonum salarkhanii Hassan (1991) and Persicaria eciliata Hassan (1996) belong to the Polygonaceae, Boesenbergia islamii Yusuf and Rahman (2003), Curcuma roxburghii Rahman and Yusuf (2012), Curcuma wallichii Rahman and Yusuf (2012), Curcuma wilcockii Rahman and Yusuf (2012), Globba rahmanii Yusuf (2003), Mantisia salarkhanii Rahman and Yusuf (2002), Zingiber salarkhanii Rahman and Yusuf (2013) belong to the Zingiberaceae, Cuscuta chittagongensis Gupta et al. (1983) belong to the Cuscutaceae, Gomphostemma salarkhaniana Khanamand Hassan (2003) of the Lamiaceae, Gymnema acuminata var. glabrum Rahman and Wilcock (1990), Tylophora indica var. intermedia Rahman and Wilcock (1988) belong to the family Asclepiadaceae, Periploca acuminate Rahman and Wilcock(1991) belonging to the Periplocaceae. The distribution of these new taxa outside Bangladesh are not yet known, hence are regarded as endemic to Bangladesh. Besides, more than 220 species of angiosperms were reported as new records from the flora of Bangladesh by different workers, like, MS Khan, AM Huq, MK Mia, M Halim, MM Rahman H Ara, B Khan, SN Uddin of National Herbarium; MA Hassan, M Begum, MO Rahman, MZ Uddin of Dhaka University, ABM Hossain of Jahangirnagar University, MA Rahman, MH Rashid, SB Uddin, MK Huda, ME.Rashid of Chittagong University, DK Das, MK Alam of BFRI and M Yusuf of BCSIR Chittagong. The flora is also known to be rich with a number of type species and endemics at or below species level. Hook.f. (1872-1897) in his the Flora of British India recorded 1416 taxa from the area of Bangladesh of which more than $24 \%$ species are known to be reported based on the types from Bangladesh (Rashid 2014). Rahman and Rashid (2012, 2013) reported 29 species, including 2 varieties belonging to 19 families,as endemic to Bangladesh. Some of the noteworthy endemics are: Hedyotis thomsonii Hook.f. and Tarenna scandens Roxb. (Rubiaceae), Knema bengalensis W.J.J.O. de Wilde (Myristicaceae), Lagenandra gomezii (Schott) Bogner and Jacobson (Araceae); Limnophila cana Griff. (Schrophulariaceae), Litseaclarki Prain (Lauraceae), Nothopegia acuminate J. Sinclair(Anacardiaceae), Rotalasimpliciuscula (Kurz) Koehne (Lythraceae); Taxillustheolocarpa (Hook.f.) Alam (Loranthaceae) and Vernoniathomsoni Hook.f. (Asteraceae).

\section{Inventory of medicinal plant diversity}

Medicinal plants occurring in the flora of Bangladesh have not yet been completely inventoried. Two medicinal books (Ghani 2003, Yusuf et al. 2009) have been published with about 500 species from the flora of Bangladesh. There are also a number of sporadic publications on the medicinal plants of 
Bangladesh made by Khan and Huq (1975, Hassan and Huq (1993), Rahman et al. (2003a, 2003b, 2006, 2009). Prof. Rahman of Chittagong University for the first initiated the family wise inventorying of medicinal plants of the flora of Bangladesh and at least 18 families consisting of 313 medicinal species (out of 962 species) have been completely inventoried so far (Rahman et. al. 2009, 2012). Rahman (2018) very recently reported the result of inventory of 36 families in his Red List of Medicinal Plants of Bangladesh resulting 313 medicinal species out of 962 species which indicates more than 32\% medicinal components occurring in the flora (Rahman et al. 2008, 2011). This inventory also shows that $20 \%$ medicinal plants of the flora are environmentally threatened at various degrees which need to prioritize conservation management.

Bangladesh National Herbarium is now well equipped set up in a modern building at its own campus. But due to lack of sufficient trained staff and adequate funding, the floristic survey and flora writing could not be progressed at a faster rate. As per 3611 species and 199 families of the flora cited in EFFB (Encyclopedia of Flora and Fauna of Bangladesh) (Siddiqui 2007), it is about 17.42\% species in 75 families so far inventoried during 1972-2016 and remaining 82.58\% species belonging to 124 families are yet to be inventoried. While as per estimated number of species (c.5000 species, c. 220 families) of the flora, it is only about $12.58 \%$ species in 75 families so far inventoried and $87.42 \%$ species belonging to nearly 145 families still left. Since systematic survey of different local floras through extensive botanical explorations was made from different universities and published data were made available, it is therefore a good source to be used for completing the inventory the whole flora speedily. On the other hand, sufficient trained taxonomists, more research facilities and adequate funding are required for the Herbarium. Participatory Flora project with the university botany departments and BFRI is required for quick inventory. Collaborative research projects with the International Herbaria is to be established for enhancing training facilities and conducting inventory of the flora on urgent basis before disappearing of its vulnerable components.

\section{REFERENCES}

Ahmed, Z. U., M. A. Hassan, Z. N. T. Begum, M. Khondker, S. M. H. Kabir, M. Ahmad, A. T. A. Ahmed (eds.). 2009c. Encyclopedia of Flora and Fauna of Bangladesh. Vol. 10. Angiosperms: Dicotyledons (Ranunculaceae-Zygophyllaceae). Asiatic Society of Bangladesh, Dhaka. 580 pp.

Ahmed, Z. U., M. A. Hassan, Z. N. T. Begum, M. Khondker, S. M. H. Kabir, M. Ahmad, A. T. A. Ahmed, A. K. A. Rahman and E. U. Haque (eds.). 2008c. Encyclopedia of Flora and Fauna of Bangladesh. Vol. 12. Angiosperms: Monocotyledons (Orchidaceae-Zingiberaceae) Asiatic Society of Bangladesh, Dhaka. 505 pp.

Ahmed, Z. U., M. A. Hassan, Z. N. T. Begum, M. Khondker, S. M. H. Kabir, M. Ahmad, A. T. A. Ahmed, A. K. A. Rahman and E. U. Haque (eds.). 2008c. Encyclopedia of Flora and Fauna of Bangladesh. Vol. 12. Angiosperms: Monocotyledons (Borchidaceae-Zingiberaceae). Asiatic Society of Bangladesh, Dhaka. 505 pp.

Ahmed, Z. U., M. A. Hassan, Z. N. T. Begum, M. Khondker, S. M. H. Kabir, M. Ahmad, A. T. A. Ahmed, A. K. A. Rahman and E. U. Haque (eds.). 2008b. Encyclopedia of Flora and Fauna of Bangladesh, Vol. 7. Angiosperms: Dicotyledons (Balsaminaceae-Euphorbiaceae). Asiatic Society of Bangladesh, Dhaka. 546 pp.

Ahmed, Z. U., M. A. Hassan, Z. N. T. Begum, M. Khondker, S. M. H. Kabir, M. Ahmad, A. T. A. Ahmed, A. K. A. Rahman and E. U. Haque (eds.). 2009a. Encyclopedia of Flora and Fauna of Bangladesh. Vol. 8. Angiosperms: Dicotyledons (Fabaceae-Lythraceae) Asiatic Society of Bangladesh, Dhaka. 478 pp. 
Ahmed, Z. U., M. A. Hassan, Z. N. T. Begum, M. Khondker, S. M. H. Kabir, M. Ahmad, A. T. A. Ahmed, A. K. A. Rahman, and E. U. Haque (eds.). 2009b. Encyclopedia of Flora and Fauna of Bangladesh. Vol. 9. Angiosperms: Dicotyledons (Magnoliaceae-Punicaceae). Asiatic Society of Bangladesh, Dhaka. 488 pp.

Ahmed, Z. U., Z. N. T. Begum, M. A. Hassan, M. Khondker, S. M. H. Kabir, M. Ahmad, A. T. A. Ahmed, A. K. A. Rahman and E. U. Haque (eds.). 2008a. Encyclopedia of Flora and Fauna of Bangladesh. Vol. 6. Angiosperms: Dicotyledons (Acanthaceae-Asteraceae). Asiatic Society of Bangladesh, Dhaka. 408 pp.

Alam, M. K. 1980. Weed flora of Forest research institute campus, Chittagong. Bull. I. Pl. Taxo. Seris, Bangladesh Forest Research Institute, Chittagong.

Ara, H. and B. Khan. 2009, 2014. Flora of Bangladesh. Vols. 59-60. Bangladesh National Herbarium, Dhaka.

Ara, H., B. Khan and S. N. Uddin (eds.) 2013. Red Data Book of Vascular Plants of Bangladesh. Bangladesh National Herbarium, Dhaka, Bangladesh. 2: 1-280.

Arefin, M. K., M. M. Rahman, M. Z. Uddin and M. A. Hassan. 2011. Angiospermic flora of Satchari National Park, Habiganj, Bangladesh. Bangladesh J. Plant Taxon. 18(2): 3117-3140.

Ghani, A. 2003. Medicinal plants of Bangladesh with chemical constituents and uses. 2nd ed. Asiatic Society of Bangladesh, Dhaka. 603 pp.

Gupta, S., M. S. Khan and M. M. Huq. 1983. Cuscuta chittagonensis (Cuscutaceae) - a new species from Bangladesh. Bangladesh J. Bot. 12(1): 33-36.

Hassan, M. A. 1996. A new species of Persicaria Tourn. Ex Mill. (Polygonaceae) from Bangladesh (Persicaria eciliata Hassan). Bangladesh J. Plant Taxon. 3(2): 87-89.

Hassan, M. A. 1991. A new species of Ampelygonum Lindley (Polygonaceaea) from Bangladesh. Bangladesh J. Bot. 20(2): 246-248.

Hassan, M. A. and A. M. Huq. 1993. Amader Bonoushudi Shampad. Hassan Book House, Dhaka, Bangladesh. 184 pp.

Hossain, M. M., M. A. Hassan and M. Z. Uddin. 2005. Checklist of angiospermic flora of Lalmai Hills, Comilla, Bangladesh. Bangladesh J. Plant Taxon. 12(2): 85-96.

Huq, A. M. and M. S. Khan. 1984. A preliminary taxonomic report on the angiospermic flora of Moheskhali Island-1. Dhaka. Univ. Stud. Part B. 32(2): 19-31.

Huq, M. A. 1988. A preliminary taxonomic report on the angiospermic flora of Hatia Island, Noakhali district. Bull. Bangladesh Natl. Herb. 1: 1-10.

Huq, M. A. 1996. Preliminary studies on angiospermic flora of Kutubdia Island in Bangladesh. $J$. Asiatic Soc. Bangladesh. 12(1\&2): 59-70.

Islam, M. R., M. Z. Uddin and M. A. Hassan. 2009. An assessment of the angiospermic flora of Ramgarhupazila of Khagrachari district, Bangladesh. Bangladesh J. Plant Taxon. 16(2): 115-140.

Khan, M .S. 1972-1987. Flora of Bangladesh. Vols. 1-39. Bangladesh National Herbarium, Dhaka.

Khan, M. S. 1991. The Vegetation of Bangladesh. In: Plant life of South Asia. pp. 185 - 192. 
Khan, M. S. 1991a. Angiosperm. In: Two Centuries of Plant Studies. The Proceedings of Asiatic Society of Bangladesh., pp. 175-194.

Khan, M. S. and A. M. Huq. 1975. Medicinal plants of Bangladesh (A preliminary list giving actions and uses), Bangladesh National Herbarium, BARC, Dhaka, Bangladesh.

Khan, M. S. and A. M. Huq. 2001. The vascular flora of Chunati wildlife sanctuary in south Chittagong. Bangladesh J. Plant Taxon. 8(1): 47-64.

Khan, M. S. and F. Banu. 1969. A taxonomic report on the angiospermic flora of Chittagong Hill Tracts1 (Monocotyledons). J. Asiatic Soc. Pakistan. 14(2): 217-224.

Khan, M. S. and M. M. Rahman. 1989-2002. Flora of Bangladesh. Vols. 40-53. Bangladesh National Herbarium, Dhaka.

Khan, M. S., A. M. Huq, A. Hassan and M. Rahman. 1984. A taxonomic report on the angiospermic flora of St. Martin's Island. Dhaka Univ. Stud. Part B. 32(1): 71-84.

Khan, M. S., M. A. Rahman, M. M. Huq, K. Mia and M. A. Hassan. 1994. Assessment of Biodiversity of Teknaf Game Reserve in Bangladesh focusing on economically and ecologically important plant species. Bangladesh J. Plant Taxon. 1(1): 21-33.

Khan, M. S., M. M. Rahman and M. A. Ali. 2001. Red Data Book of Vascular Plants of Bangladesh, Bangladesh National Herbarium, Dhaka, Bangladesh. 172 pp.

Khan, M. S. 1977. Flora of Bangladesh. Bangladesh National Herbarium, Dhaka. 4: 1-40.

Khan, M. S. and F. Banu. 1972. A taxonomic report on the angiospermic flora of Chittagong Hill Tracts2 (Dicotyledons). J. Asiatic Soc. Bangladesh. 17(2): 59-88.

Khanam, M. and H. Ara. 2004-2008. Flora of Bangladesh. Vols. 56-58. Bangladesh National Herbarium, Dhaka.

Khanam, M. and M. Hassan. 2003. Gomphostemma salarkhaniana (Lamiaceae) - A new species from Bangladesh. Bangladesh J. Bot. 32(2): 63-64.

Momen, R. U., M. K. Hossain, S. M. S. Huda and B. M. Khan. 2006. Assessment of plant diversity in Chittagong University campus. J. Forest Environ. 4: 27-52.

Pasha, M. K. and M. N. Alam. 1999. A floristic account of Chittagong University Campus, Chittagong, Bangladesh. Univ. J. Sci. 23(1): 81-99.

Prain, D. 1903. Bengal Plants. (reprinted 1963). Botanical Survey of India. Vol. 1 and 2. Bishen SinghMahendra Pal Singh, DehraDun, India., pp. 1-490, pp. 491-1013.

Rahman M. A. 2003. Some threatened forest species: IUCN Red List Categories. Biod. Newletter Bangladesh. 7(1\&2): 1-2.

Rahman, M. A. and M. Yusuf. 2012. Three new species of Curcuma L. (Zingireaceae) from Bangladesh. Bangladesh J. Pl. Taxon. 19(1): 79-84.

Rahman, M. A. (ed.). 2013. Red Data Book of Flowering Plants of Bangladesh. Vol. 1. Chittagong, Bangladesh. 256 pp.

Rahman, M. A. 2015. A report on the flora of Bariadhala National Park and Hazarikhil Wildlife Sanctuary. Report of the "Protected Area Management Plan for Hazarikhil and Baraiyadhala National Parks" under Strengthening Regional Co-operation for Wildlife Protection Project. 33 pp. 
Rahman, M. A. 2017. Inventory of plant diversity in Hazarikhil Wildlife Sanctuary of Chittagong and their conservation management. J. biodivers. conserv. bioresour. manag. 3(2): 43-56.

Rahman, M. A. and M. Yusuf. 2002. Mantisia salarkhanii Rahman andYusuf (Zingiberaceae) sp. nov. a new species from Bangladesh. Saudi J. Bio. Sci. 9(2): 105-110.

Rahman, M. A. and C. C. Wilcock. 1989. Notes on tropical Asian Asclepiadaceae II. J. Eco. Tax. Bot 13(1): $181-185$.

Rahman, M. A. and C. C. Wilcock. 1990. Notes on tropical Asian Asclepiadaceae III. Blumea. 34(2): 519-520.

Rahman, M. A. and M. E. Rashid. 2012. Distribution of Indian endemics to the flora of Bangladesh and their status of occurrence. Physiol. Ecol. \& Environ. Sci. 3(1\&2): 23-33.

Rahman, M. A. and M. E. Rashid. 2013. Endemic species of Bangladesh: Taxonomy, distribution, status of occurrence and conservation. Int. J. Environ. Nepal. 2(1): 231-249.

Rahman, M. A. and M. H. Rashid. 2009. Medicinal plant diversity in the Flora of Bangladesh 1: A report on eight angiosperm families. Plant Archives. 9(2): 701-713.

Rahman, M. A. and S. B. Uddin. 1997. Assessment of plant diversity of Sitakunda in Chittagong. Bangladesh J. Plant Taxon. 4(1): 17-36.

Rahman, M. A., B. Khodeja, M. E. Rashid and M. H. Rashid. 2012. Medicinal plant diversity in the Flora of Bangladesh and their conservation 2: A report on ten angiosperm families. Plant Archives. 12(2): 1023-1035.

Rahman, M. A., M. F. Ahmed and M. E. Rashid. 2016. Plant diversity of the Hakaluki Haor of Bangladesh and its management issues. J. biodivers. conserve.bioresour. manag. 2(1): 47-60.

Rahman, M. A., M. N. Uddin, M. E. Rashid, M. N. Uddin and M. M. Islam. 2012. Floristic Diversity in Rampahar reserve forest of Kaptai, Rangamati. Biod. Bull. Bangladesh. 6: 1-31.

Rahman, M. A., S. B. Uddin and C. C. Wilcock. 2003a. Indigenous Knowledge of herbal medicine in Bangladesh 1: for the cure of Jaundice. Hamdard Medicus. 46(2): 25-28.

Rahman, M. A., S. B. Uddin and C. C. Wilcock. 2003b. Indigenous Knowledge of herbal medicine in Bangladesh 2: diarrhoea, dysentery, indigestion and stomach pains. J. Med. Arom. Pl. Sci. 25: 1001-1009.

Rahman, M. A., S. B. Uddin and C. C. Wilcock. 2006. Medicinal plants used by Chakma tribe in Hill Tracts Districts of Bangladesh. Indian J. Tradtl Knowledge. 6(3): 508-517.

Rahman, M. A., S. C. Das and M. E. Rashid. 2010. The IUCN Red List Categories of Angiosperm Plants of Bangladesh and their Conservation. J. Taxon. Biodiv. Res. 4: 17-34.

Rahman, M. M. 2003. Flora of Bangladesh. Bangladesh National Herbarium, Dhaka. 54: 1-79.

Rahman, M. M. and M. Khanam. 2003. Flora of Bangladesh. Bangladesh National Herbarium, Dhaka. 55: $1-11$.

Rahman, M. O. and M. A. Hassan. 1995. Angiospermic flora of Bhawal National Park, Gazipur (Bangladesh). Bangladesh J. Plant Taxon. 2(1 \& 2): 47-80.

Rahman, M. A. and C. C. Wilcock. 1991. A new species of Periploca (Periplocaceae) from Bangladesh. Bot. J. Linn. Soc. 110: 373-377. 
Rahman, M. A. and M. Yusuf. 2013. Zingiber salarkhanii (Zingiberaceae) - a new species from Bangladesh. Bangladesh J. Pl. Taxon. 20(2): 239-242.

Rashid, M. E. 2014. Current nomenclature and taxonomic status of the plants recorded from the area of Bangladesh in volumes III-VII of the Hooker's "Flora of British India". Unpublished Ph.D. Thesis. Department of Botany, University of Chittagong.

Rashid, S. H. and M. M. K. Mia. 2001. Angiospermic flora of Madhupur National Park, Tangail, Bangladesh. Bangladesh J. Plant Taxon. 8(2): 63-82.

Siddiqui, K. U., M. A. Islam, Z. U. Ahmed, Z. N. T. Begum, M. A. Hassan, M. Khondker, M. M. Rahman, S. M. H. Kabir, M. Ahmad, A. T. A. Ahmed, A. K. A. Rahman and E. U. Haque (eds.). 2007. Encyclopedia of Flora and Fauna of Bangladesh. Vol. 11. Angiosperms: Monocotyledons (Agavaceae-Najadaceae). Asiatic Society of Bangladesh, Dhaka. 399 pp.

Tutul, E., M. Z. Uddin, M. O. Rahman and M. A. Hassan. 2009. Angiospermic flora of Runctia Sal Forest, Bangladesh-1. Liliopsida (Monocots). Bangladesh J. Plant Taxon. 16 (1): 83-90.

Tutul, E., M. Z. Uddin, M. O. Rahman and M. A. Hassan. 2010. Angiospermic flora of Runctia Sal Forest, Bangladesh-2. Magnoliopsida (Dicots). Bangladesh J. Plant Taxon. 17(1): 33-53.

Uddin, M. G., M. E. Rashid and M. A. Rahman. 2013. Plant diversity in Upper Rezu Reserve forest of Ramu, Cox's Bazar. Biod. Bull. Bangladesh. 7: 1-33.

Uddin, M. Z. and M. A. Hassan. 2004. Flora of Rema-Kalenga Wildlife Sanctuary. IUCN. Bangladesh Country Office, Dhaka, Bangladesh., pp. 1-120.

Uddin, M. Z. and M. A. Hassan. 2010. Angiospermic diversity of Lawachara National Park (Bangladesh): A preliminary assessment. Bangladesh J. Plant Taxon. 17(1): 9-22.

Uddin, M. Z., M. A. Hassan and M. S. Khan. 2002. An Annotated Checklist of angiospermic Flora of Rema-Kalenga Wildlife Sanctuary (Habiganj) in Bangladesh-I. Liliopsida (Monocots). Bangladesh J. Plant Taxon. 9(2): 57-66.

Uddin, M. Z., M. A. Hassan and M. S. Khan. 2003. An Annotated Checklist of angiospermic Flora of Rema-Kalenga Wildlife Sanctuary, (Habiganj) in Bangladesh-IIa. Magnoliopsida (Dicots). Bangladesh J. Plant Taxon. 10(1): 79-94.

Uddin, S. B. and M. A. Rahman. 1999. Angiospermic flora of Himchari National Park, Cox's Bazar. Bangladesh J. Plant Taxon. 6(1): 31-68.

Uddin, S. N. 2012. Floristic studies on Rampahar and Sitapahar reserve forests, Rangamati, Bangladesh. Unpublished Ph.D. Thesis, Department of Botany, University of Dhaka.

Uddin, S. N. and M. A. Hassan. 2012. Angiospermic flora of Rampahar Reserve forest under Rangamati district in Bangladseh. I. Liliopsida (Monocots). Bangladesh J. Plant Taxon. 19(1): 37-44.

Uddin, S. N., M. S. Khan, M. A. Hassan and M. K. Alam. 1998. An Annotated Checklist of angiospermic flora of Sitapahar at Kaptai in Bangladseh. Bangladesh J. Plant Taxon. 5(1): 13-46.

Yusuf, M. and M. A. Rahman. 2003. Boesenbergia islamii Yusuf et Rahman (Zingiberaceae) sp.nov.a new species from Bangladesh. Saudi J. Bio. Sci. 10(1): 51-55.

Yusuf, M. 2003. Globba rahmanii Yusuf (Zingiberaceae) - a new species from Bangladesh. J. Econ. Taxon. Bot. 28(1): 87-90. 
Yusuf, M., J. Begum, M. N. Hoque and J. U. Chowdhury. 2009. Medicinal Plants of Bangladesh. (Revised and Enlarged). 2nd ed. BCSIR Laboratories, Dhaka, Bangladesh. 794 pp.

Yusuf, M., M. O. Rahman, M. S. Khan and S. Huq. 1997. Angiospermic flora of Chanda Beel, Gopalganj district in Bangladesh. Bangladesh J. Plant Taxon. 4(2): 25-36. 